\title{
Rancang Bangun Sistem Informasi Produk Unggulan Daerah Usaha Kecil Menengah
}

Kauntu Natasya Novia Febriana ${ }^{1)}$, Yaulie D.Y. Rindengan ${ }^{2)}$, Alwin M. Sambul'

Program Studi Teknik Informatika, Fakultas Teknik, Universitas Sam Ratulangi, Manado, Indonesia. kauntunatasya06@gmail.com ${ }^{1)}$,rindengan@unsrat.ac.id ${ }^{2}$, asambul@unsrat.ac.id ${ }^{3}$ )

\begin{abstract}
Abstrak - Perkembangan UKM (Usaha Kecil Menengah) yang ada di Sulawesi Utara sangat diharapkan keberadaannya dalam menciptakan dan memproduksi hasil karya suatu daerah melalui teknologi informasi. Oleh karena itu, potensi dari UKM yang ada di Sulawesi Utara diharapkan dapat bersaing dengan produk luar dalam mempromosikan produk lokal dalam negeri. Sistem informasi produk unggulan daerah usaha kecil menengah berbasis website dapat difungsikan untuk mengakses berbagai produk unggulan dengan bermacam kategori yang disediakan agar membantu anggota UKM dan masyarakat dalam mencari dan mempromosikan produk unggulan daerah. Metode rancang bangun sistem informasi produk unggulan daerah usaha kecil menengah adalah rapid application development (RAD) yang tujuan utamanya memenuhi harapan dari pengguna dengan waktu yang relatif singkat dan menghasilkan kualitas sistem yang lebih baik, sedangkan objek penelitiannya dilaksanakan di Dinas Perindustrian dan Perdagangan Provinsi Sulawesi Utara.
\end{abstract}

Kata Kunci : UKM, sistem informasi, media promosi, produk unggulan daerah, website, rapid application development.

Abstract - The development of SMEs (Small and Medium Enterprises) in North Sulawesi is expected to exist in creating and producing the work of an area through information technology. Therefore, the potential of SMEs in North Sulawesi is expected to be able to compete with outside products in promoting local products. With the establishment of a superior product information system in the area of website-based small and medium enterprises, it can be used to access a variety of superior products with various categories provided to help SME members and the public in finding and promoting regional superior products. The design method of the superior product information system for small and medium enterprises is rapid application development (RAD) whose main purpose is to meet the expectations of users in a relatively short time and produce better system quality, while the object of research is carried out at the North Sulawesi Industry and Trade Office.

Keywords : information system, promotion media, rapid application development, regional superior produts, SME, website.

\section{PENDAHULUAN}

Dalam perkembangan zaman sekarang ini teknologi informasi sangatlah penting, karena semua kegiatan yang dilakukan memerlukan informasi. Teknologi informasi dan komunikasi memegang peranan yang sangat penting di dalam suatu organisasi yang cukup besar.

Dalam hal ini media promosi adalah salah satu usaha untuk memperkenalkan dan mempromosikan produk unggulan hasil daerah yang ada di Sulawesi Utara dengan menggunakan teknologi informasi. Promosi menggunakan media internet ini dilatarbelakangi oleh meningkatnya pengguna internet di zaman sekarang ini. Masyarakat dalam negeri ataupun luar negeri sangat ingin mengetahui produk apa yang menjadi unggulan dari perusahaan-perusahaan atau pengrajin yang memproduksi produk unggulan tersebut.

Perkembangan UKM (Usaha Kecil Menengah) yang ada di Sulawesi Utara sangat diharapkan keberadaannya dalam menciptakan dan memproduksi hasil karya suatu daerah melalui teknologi informasi. Oleh karena itu, potensi dari UKM yang ada di Sulawesi Utara dapat bersaing dengan produk luar dalam mempromosikan produk lokal dalam negeri.

Penerapan sistem informasi pada UKM oleh banyak pelaku bisnis dapat meningkatkan daya saing melalui nilai tambah pada produk dan layanan yang dihasilkannya dan bergantung juga pada aspek kemampuan sumber daya manusia. Semakin tinggi kemampuan sumber daya manusia yang menguasai teknologi informasi, semakin tinggi juga pemanfaatan sistem informasi. Dengan demikian, penerapan sistem informasi merupakan keharusan agar UKM bisa bersaing dan meningkatkan usahanya.

Saat ini di Dinas Perindustrian dan Perdagangan Provinsi Sulawesi Utara khususnya bidang IKM (Industri Kecil Menengah) media 
promosi masih sangat diperlukan dalam memperkenalkan produk unggulan daerah. Selama ini pengenalan produk-produk unggulan daerah lebih banyak dilakukan dengan diadakannya pameran-pameran di daerah yang ada di Indonesia. Namun hal ini masih belum efektif dalam mempromosikan produk unggulan tersebut, dikarenakan jarak, waktu, tempat dan informasi yang masih terbatas diketahui oleh siapapun. Selain itu, pengolahan data usaha kecil menengah masih dilakukan secara konvensional, sehingga masyarakat sulit untuk mendapatkan informasi tentang perusahaan atau pelaku usaha serta kapasitas dan jumlah perkembangan produk unggulan setiap tahun yang dihasilkan oleh UKM.

\section{A. Definisi Sistem Informasi}

Sistem informasi adalah sistem informasi mencakup sejumlah komponen (manusia, komputer, teknologi informasi, dan prosedur kerja), ada sesuatu yang diproses (data menjadi informasi), dan dimaksudkan untuk mencapai suatu sasaran atau tujuan. (Kadir, 2003)

Adapun kegiatan sistem informasi adalah sebagai berikut :

1. Input, yaitu menggambarkan suatu kegiatan untuk menyediakan data untuk diproses.

2. Proses, yaitu menggambarkan bagaimana suatu data diproses untuk menghasilkan suatu informasi yang bernilai tambah.

3. Output, yaitu suatu kegiatan untuk menghasilkan laporan dari suatu proses informasi.

4. Penyimpanan, yaitu suatu kegiatan untuk memelihara dan menyimpan data.

5. Control, yaitu suatu aktivitas untuk menjamin bahwa sistem informasi tersebut berjalan sesuai dengan yang diharapkan.

\section{B. Media Promosi}

Media diartikan perantara atau pengantar pesan dari pengirim kepada penerima pesan. Secara harfiah media mempunyai arti perantara atau pengantar. Promosi adalah suatu bentuk komunikasi pemasaran. Komunikasi pemasaran adalah aktivitas pemasaran yang berusaha menyebarkan informasi, mempengaruhi/membujuk, dan mengingatkan pasar sasaran atas perusahaan dan produknya agar bersedia menerima, membeli, dan loyal pada produk yang ditawarkan perusahaan yang bersangkutan. Sedangkan informasi memiliki arti data yang diolah menjadi bentuk yang lebih berguna dan yang lebih berarti bagi yang menerimanya dan bermanfaat dalam pengambilan keputusan saat ini atau mendatang.

Salah satu strategi komunikasi yang paling efektif adalah promosi. Promosi merupakan elemen dalam marketing mix yang dipakai perusahaan untuk memasarkan kebutuhannya. Promosi dipandang sebagai, arus informasi atau persuasi satu arah yang dibuat untuk mengarahkan seseorang atau organisasi kepada tindakan untuk menciptakan pertukaran dalam pemasaran (Swastha, 1987).

\section{UKM (Usaha Kecil Menengah)}

1) Definisi UKM

Usaha kecil menengah (UKM) ialah salah satu bagian penting dari perekonomian suatu negara maupun daerah, begitu juga dengan negara Indonesia. UKM sangat memiliki peranan penting dalam lajunya perekonomian masyarakat. UKM juga sangat membantu negara atau pemerntah dalam hal penciptaan lapangan kerja baru dan lewat UKM juga banyak tercipta unit-unit kerja baru yang menggunakan tenaga-tenaga baru yang dapat mendukung pendapatan rumah tangga. Selain dari itu UKM juga memiliki fleksibilitas yang tinggi jika dibandingkan dengan usaha yang berkapasitas lebih besar. UKM perlu perhatian yang khusus dan di dukung oleh informasi yang akurat, agar terjadi link bisnis yang terarah antara pelaku usaha kecil dan menengah dengan elemen daya saing usaha, yaitu jaringan pasar.

Menurut Badan Pusat Statistik (BPS), pengertian usaha kecil menengah (UKM) berdasarkan tenaga kerja. Usaha kecil merupakan usaha yang memiliki jumlah tenaga kerja 5 orang sampai 19 orang, sedangkan usaha menengah merupakan usaha yang memiliki jumlah tenaga kerja 20 orang sampai dengan 99 orang.

Menurut undang-undang nomor 20 tahun 2008 tentang usaha mikro, kecil dan menengah (UMKM).

1. Usaha mikro adalah usaha produktif milik orang perorangan dan/atau badan usaha perorangan yang memenuhi kriteria usaha mikro sebagaiamana diatur dalam undangundang ini.

2. Usaha kecil adalah usaha ekonomi produktif yang berdiri sendiri, yang dilakukan oleh orang perorangan atau badan usaha yang bukan merupakan anak perusahaan atau bukan cabang perusahaan yang dimiliki, dikuasai, atau menjadi bagian baik langsung maupun tidak langsung dari usaha menengah atau usaha besar yang memenuhi kriteria usaha kecil sebagaimana dimaksud dalam undangundang ini.

3. Usaha menengah adalah usaha ekonomi produktif yang berdiri sendiri, yang dilakukan oleh orang perseorangna atau badan usaha yang bukan merupakan anak perusahaan atau cabang perusahaan yang dimiliki, dikuasai, atau menjadi bagian baik langsung maupun tidak langsung dengan usaha kecil atau usaha besar dengan jumlah kekayaan bersih atau 
hasil penjualan tahunan sebagaimana diatur dalam undang-undang ini. [1]

2) Klasifikasi UKM

Dalam perspektif perkembangannya, UKM dikelompokan menjadi 4 kelompok yaitu :

1. Livelihood Activities adalah UKM yang digunakan sebagai kesempatan kerja untuk mencari nafkah, yang lebih umum dikenal sebagai sektor informal.

2. Micro Enterprise adalah UKM yang memiliki sifat pengrajin tetapi belum mempunyai sifat kewirausahaan.

3. Small Dynamic Enterprise adalah UKM yang telah memiliki jiwa kewirausahaan dan mampu menerima pekerjaan subkontrak dan ekspor.

4. Fast Moving Enterprise adalah UKM yang telah memiliki jiwa kewirausahaan dan akan melakukan transformasi menjadi usaha besar (Arief Rahmana, 2009).

3) Ciri-ciri Usaha Kecil Menengah (UKM)

Berikut merupakan ciri-ciri dari usaha kecil menengah (UKM), yaitu :

1. Bahan baku mudah diperoleh

2. Menggunakan teknologi sederhana sehingga mudah dilakukan ahli teknologi.

3. Keterampilan dasar umumnya sudah dimiliki secara turun-temurun.

4. Bersifat padat karya atau menyerap tenaga kerja yang cukup banyak.

5. Peluang besar cukup luas, sebagian besar produknya terserap di pasar lokal/dosmetik dan tidak tertutup sebagian lainnya berpotensi untuk diekspor.

6. Melibatkan masyarakat ekonomi lemah setempat, secara ekonomis menguntungkan.

4) Permasalahan UKM

Pada umumnya permasalahan yang dihadapi oleh usaha kecil menengah (UKM) antara lain

1. Faktor Internal

Kurangnya permodalan-permodalan merupakan faktor utama yang diperlukan untuk mengembangkan suatu unit usaha. Kurangnya permodalan UKM, karena pada umumnya usaha kecil dan menengah merupakan usaha perorangan atau perusahaan yang sifatnya tertutup.

2. Sumber Daya Manusia yang Terbatas Keterbatasan sumber daya manusia (SDM) usaha kecil baik dari segi pendidikan formal maupun pengetahuan dan keterampilannya sangat berpengaruh pada manajemen pengelolaan usahanya, sehingga usaha tersebut sangat sulit untuk berkembang secara optimal.

3. Lemahnya Jaringan Usaha dan Kemampuan Penetrasi Usaha Kecil

Jaringan usaha yang sangat terbatas dan kemampuan penetrasi rendah maka produk yang dihasilkan jumlahnya sangat terbatas dan mempunyai kualitas yang kurang kompetitif.

4. Faktor Eksternal

Iklim usaha belum sepenuhnya kondusif dengan kebijaksanaan pemerintah untuk menumbuhkembangkan usaha kecil dan menengah. Terlihat dari masih terjadinya persaingan yang kurang sehat antara pengusaha-pengusaha kecil dan pengusaha besar.

5. Terbatasnya Sarana dan Prasarana Usaha Kurangnya informasi yang berhubungan dengan kemajuan ilmu pengetahuan dan teknologi menyebabkan sarana dan prasarana yang mereka miliki juga tidak cepat berkembang dan kurang mendukung kemajuan usaha.

6. Sifat Produk dengan Lifetime Pendek Sebagian besar produk industri kecil memiliki ciri atau karakteristik sebagai produk-produk fashion dan kerajinan dengan lifetime yang pendek.

7. Terbatasnya Akses Pasar

Akses pasar akan menyebabkan produk yang dihasilkan tidak dapat dipasarkan secara kompetitif baik di pasar nasional maupun internasional. (Jafar Hafsah, 2004)

5) Upaya untuk mengembangkan UKM

Berikut adalah beberapa upaya dalam mengembangkan UKM, yaitu :

1. Penciptaan iklim usaha yang kondusif

2. Mengusahakan keamanan berusaha dan ketentraman serta penyederhanaan prosedur perizinan usaha dan keringanan pajak.

3. Perlindungan usaha jenis-jenis tertentu terutama jenis usaha tradisional yang merupakan usaha golongan ekonomi lemah, harus mendapatkan perlindungan dari pemerintah baik melalui undangundang maupun peraturan pemerintah.

4. Mengembangkan promosi guna lebih mempercepat proses kemitraan antara UKM dengan usaha besar diperlukan media khusus dalam upaya mempromosikan produk-produk yang dihasilkan.

6) Aspek dalam menumbuhkan iklim usaha Berikut adalah beberapa aspek yang ditetapkan pemerintah dalam perundang- 
undangan dan kebijakan dalam menumbuhkan iklim usaha bagi usaha kecil menengah.

1. Aspek Pendanaan

Pemerintah menetapkan kebijakan untuk memperluas sumber pendanaan, meningkatkan akses terhadap sumber pendanaan, memberikan kemudahan dalam pendanaan.

2. Aspek Persaingan

Pemerintah menetapkan kebijakan untuk meningkatkan kerja sama sesama usaha kecil dalam bentuk koperasi, asosiasi, dan himpunan kelompok usaha untuk memperkuat posisi tawar usaha kecil, mencegah stuktur pasar yang dapat melahirkan persaingan yang tidak wajar dalam bentuk monopoli, oligopoli, dan monopsoni yang merugikan usaha kecil, serta mencegah terjadinya peguasaan pasar dan pemusatan usaha oleh orang perorang atau kelompok tertentu yang merugikan usaha kecil.

3. Aspek Informasi

Pemerintah menetapkan kebijakan untuk membentuk dan memanfaatkan bank data dan jaringan informasi bisnis serta mengadakan dan menyebarkan informasi mengenai pasar, teknologi, desain dan mutu.

4. Aspek Kemitraan

Pemerintah menetapkan kebijakan untuk mewujudkan kemitraan dan mencegah terjadinya hal-hal yang merugikan usaha kecil dengan usaha menengah dan usaha besar.

5. Aspek Perizinan

Pemerintah menetapkan kebijakan untuk menyerderhanakan tata cara dan jenis perizinan dengan mengupayakan terwujudnya pelayanan sistem satu atap dan memberikan kemudahan persyaratan untuk memperoleh perizinan.

6. Aspek Perlindungan

Pemerintah menetapan kebijakan untuk menentukan peruntukan tempat usaha yang meliputi pemberian lokasi di pasar, ruang pertokoan, lokasi sentra industri, lokasi pertanian rakyat, lokasi pertambangan rakyat, dan lokasi yang wajar bagi pedagang kaki lima serta lokasi lainnya, mencadangkan bidang dan jenis kegiatan usaha yang memiliki kekhususan proses, bersifat padat karya, serta mempunyai nilai seni budaya yang bersifat khusus dan turun-temurun mengutamakan penggunaan produk yang dihasilkan usaha kecil melalui pengadaan secara langsung dari usaha kecil mengatur pengadaan barang dan jasa dan pemborongan kerja pemerintah serta memberikan bantuan konsultan hukum dan pembelaan.

7) Pengembangan UKM di Indonesia Dalam pengembangan UKM juga terdapat beberapa faktor yang menyebabkan rendahnya tingkat UKM, yaitu penguasaan teknologi dan kemampuan wirausaha.

Dalam UKM ada beberapa faktor penentu keberhasilan usaha, yaitu sebagai berikut :

1. Kemampuan mengembangkan dan mengimplementasikan rencana perusahaan, baik jangka pendek maupun panjang.

2. Kapabilitas dan kompotensi manajemen

3. Perusahaan dapat memenuhi kebutuhan modal untuk menjalankan usaha. [2]

\section{PUD (Produk Unggulan Daerah)}

Produk Unggulan Daerah (PUD) merupakan suatu barang atau jasa yang dimiliki dan dikuasai oleh suatu daerah, yang mempunyai nilai ekonomis dan daya saing tinggi serta menyerap tenaga kerja dalam jumlah besar, yang diproduksi berdasarkan pertimbangan kelayakan teknis (bahan baku dan pasar), talenta masyarakat dan kelembagaan (penguasaan teknologi, kemampuan sumberdaya manusia, dukungan infrastruktur, dan kondisi sosial budaya setempat) yang berkembang di lokasi tertentu. Pengembangan ekonomi lokal merupakan proses membangun dialog dan kemitraan aksi para pihak yang meliputi pemerintah daerah, para pengusaha, dan organisasi-organisasi masyarakat lokal. Pilar-pilar pokok strateginya adalah meningkatkan daya tarik, daya tahan, dan daya saing ekonomi lokal. Tujuan utamanya adalah untuk menciptakan pertumbuhan yang tinggi dan pembangunan berkelanjutan yang bermanfaat bagi semua pihak di daerah dalam rangka meningkatkan kesempatan kerja baru, peningkatan dan pengurangan kemiskinan secara signifikan.

Produk unggulan daerah menggambarkan kemampuan daerah menghasilkan produk, menciptakan nilai, memanfaatkan sumber daya secara nyata, memberi kesempatan kerja, mendatangkan pendapatan bagi masyarakat maupun pemerintah, memiliki prospek untuk meningkatkan produktivitas dan investasinya. Sebuah produk dikatakan unggul jika memiliki daya saing sehingga mampu untuk menangkal produk pesaing di pasar domestik atau menembus pasar ekspor (Sudarsono, 2001).

\section{E. Website}

Website merupakan kumpulan halaman halaman yang berisi informasi yang disimpan dalam internet yang bisa diakses atau dilihat melalui jaringan internet pada perangkat-perangkat yang bisa mengakses internet itu sendiri seperti komputer. Definisi kata web adalah web sebenarnya penyederhanaan dari sebuah istilah 
dalam dunia komputer yaitu world wide web yang merupakan bagian dari teknologi internet.

World wide web atau disingkat dengan nama www, merupakan sebuah sistem jaringan berbasis client-server yang mempergunakan protokol HTTP (Hyperteks Transfer Protocol) dan TCP/IP (Transmisson Control Protocol / Internet Protocol) sebagai medianya. Karena kedua sistem ini mempunyai hubungan yang sangat erat, maka untuk saat ini sulit untuk membedakan antara HTTP dengan WWW.

\section{F. Komponen Kebutuhan Sistem}

1) HTML (Hyper Text Markup Language)

Hyper Text Markup Language (HTML) adalah suatu bahasa untuk menampilkan konten dalam web. HTML sendiri adalah bahasa pemrograman yang bebas, artinya tidak dimiliki oleh siapa pun, pengembangannya dilakukan oleh banyak orang di berbagai negara dan bisa dikatakan sebagai sebuah bahasa yang dikembangkan bersama-sama secara global. Sebuah dokumen HTML sendiri adalah dokumen teks yang dapat diedit oleh editor teks apapun.

HTML (Hyper Text Markup Language) merupakan sebuah bahasa script yang digunakan untuk menampilkan isi halaman website secara terstruktur dan terinci. HTML diartikan sebagai bahasa yang berupa tag untuk menampilkan informasi dengan memanfaatkan protokol http, dengan menampilkan content berupa text, gambar, audio dan video.

2) PHP (Hypertext Preprocessing)

Hypertext Preprocessing (PHP) adalah suatu bahasa pemrograman open source yang digunakan secara luas terutama untuk pengembangan web dan dapat disimpan dalam bentuk HTML. Penggunaan PHP memungkinkan web dapat dinamis sehingga maintenance situs web tersebut menjadi lebih mudah dan efisien. Keuntungan utama menggunakan PHP adalah script PHP tidak benar-benar sederhana bagi pemula, tetapi menyediakan banyak fitur tambahan untuk programmer profesional. Meskipun PHP lebih difokuskan sebagai script server side.

3) CSS (Cascading Style Sheet)

Cascading Style Sheet (CSS) merupakan aturan untuk mengendalikan beberapa komponen dalam sebuah web sehingga akan lebih terstruktur. CSS bukan merupakan bahasa pemograman, sama halnya styles dalam aplikasi pengolahan kata seperti microsoft word yang dapat mengatur beberapa style, misalnya heading, subbab, bodytext, footer, images, dan style lainnya untuk dapat digunakan bersama-sama dalam beberapa berkas (file). Pada umumnya CSS dipakai untuk memformat tampilan halaman web yang dibuat dengan bahasa HTML dan XHTML.

CSS dapat mengendalikan ukuran gambar, warna bagian tubuh pada teks, warna tabel, ukuran border, warna border, warna hyperlink, warna mouse over, spasi antar paragraf, spasi antar teks, margin kiri, kanan, atas, bawah, dan parameter lainnya.

4) MySQL

MySQL adalah teknologi database terbuka dan sistem penyimpanan data dengan menawarkan kehandalan besar dan kemudahan penggunaannya. Fitur MySQL dilengkapi dengan dokumentasi gratis berbagi kode yang berhubungan dengan berkomunikasi dengan database MySQL.

MySQL merupakan software yang tergolong sebagai DBMS (Database Management System) yang bersifat open source untuk berkomunikasi dengan basis data atau database yaitu dengan Structured Query Language (SQL). MySQL dapat berjalan di berbagai platform, antara lain linux, windows dan sebagainya.

\section{G. RAD (Rapid Application Development)}

Rapid Application Development (RAD) adalah salah satu metode pengembangan suatu sistem informasi dengan waktu yang relatif singkat.

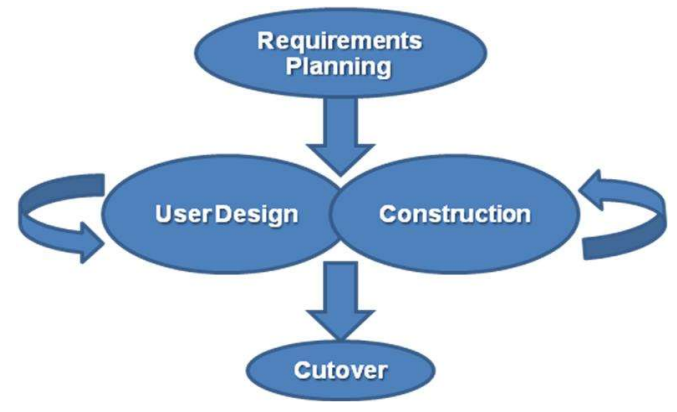

Gambar 1. RAD (Rapid Application Development)

Tujuan utama dari semua metode sistem development adalah memberikan suatu sistem yang dapat memenuhi harapan dari para pemakai, akan tetapi sering kali di dalam melakukan pengembangan suatu sistem tidak melibatkan para pemakai sistem secara langsung, sehingga hal ini menyebabkan sistem informasi yang dibuat jauh dari harapan pemakai yang dapat berakibat sistem tersebut walaupun dapat diterima tetapi para pemakai belum ingin menggunakannya atau bahkan para pemakai menolak menggunakannya.

Pada saat RAD diimplementasikan, maka para pemakai bisa menjadi bagian dari keseluruhan 
proses pengembangan sistem dengan bertindak sebagai pengambil keputusan pada setiap tahap pengembangan. RAD bisa menghasilkan suatu sistem dengan cepat karena sistem yang dikembangkan dapat memenuhi keinginan dari para pemakai sehingga dapat mengurangi waktu untuk pengembangan ulang setelah tahap implementasi.

Metode RAD menggunakan metode iteratif (berulang) dalam mengembangkan sistem dimana model bekerja sistem dikonstruksikan di awal tahap pengembangan dengan tujuan menetapkan kebutuhan pengguna.

\section{METODOLOGI PENELITIAN}

\section{A. Metode Pengumpulan Data}

Metode pengumpulan data yang digunakan peneliti pada penelitian ini adalah sebagai berikut :

1. Studi Pustaka

Studi pustaka merupakan suatu metode pengumpulan data yang diperoleh dari buku literatur maupun referensi dari internet tentang sistem informasi produk unggulan daerah usaha kecil menengah.Kuisioner

2. Wawancara

Wawancara merupakan suatu metode pengumpulan data yang diperoleh dengan sesi tatap muka dan tanya jawab langsung dengan narasumber atau pihak-pihak yang berkepentingan dalam penelitian tentang sistem informasi produk unggulan daerah usaha kecil menengah.

3. Kuisioner

Kuisioner merupakan suatu metode pengumpulan data yang dilakukan dengan cara memberikan daftar yang berisi pertanyaan yang khusus untuk mengumpulkan pendapat dari pihak-pihak yang berkaitan dengan penelitian tentang sistem informasi produk unggulan daerah usaha kecil menengah.

4. Observasi

Observasi merupakan suatu metode pengumpulan data yang dilakukan melalui pengamatan dan pencatatan data yang dijadikan objek penelitian secara langsung.

\section{B. Definisi Kebutuhan}

1) Problem Statement Matrix

Perencanaan awal sistem dimulai dengan dilakukannya identifikasi masalah yang dimuat dalam tabel problem statement matrix untuk mendifinisikan masalah yang dihadapi secara garis besar agar dapat dicari solusinya.

\begin{tabular}{|c|c|}
\hline $\begin{array}{l}\text { The } \\
\text { problem of }\end{array}$ & $\begin{array}{l}\text { Masih minimnya pengetahuan masyarakat } \\
\text { terhadap produk unggulan daerah yang } \\
\text { dihasilkan oleh UKM. } \\
\text { Anggota UKM masih kurang mempromosikan } \\
\text { hasil produk unggulan. } \\
\text { Pengolahan data UKM masih dilakukan secara } \\
\text { konvensional. }\end{array}$ \\
\hline Affects & $\begin{array}{l}\text { Produk unggulan daerah dan pelaku usaha } \\
\text { UKM. }\end{array}$ \\
\hline $\begin{array}{l}\text { The impact } \\
\text { of which is }\end{array}$ & $\begin{array}{l}\text { Masyarakat kurang/sulit mendapatkan } \\
\text { informasi tentang produk unggulan daerah. } \\
\text { Sulitnya pelaku usaha mempromosikan produk } \\
\text { unggulan secara cepat dan tepat. } \\
\text { Harus mencari data UKM melalui instansi } \\
\text { pemerintahan. }\end{array}$ \\
\hline $\begin{array}{l}\text { A } \\
\text { successful } \\
\text { solution } \\
\text { would be }\end{array}$ & $\begin{array}{l}\text { Merancang dan membangun sebuah sistem } \\
\text { informasi produk unggulan daerah usaha kecil } \\
\text { menengah dengan menampilkan informasi } \\
\text { detail tentang produk unggulan dan } \\
\text { mempermudah para anggota UKM untuk } \\
\text { mempromosikan hasil produk unggulan. }\end{array}$ \\
\hline
\end{tabular}

Tabel 1. Problem Statement Matrix

\section{Metode Pengembangan Sistem}

Dalam merancang dan membangun sistem informasi produk unggulan daerah usaha kecil menengah, penulis menggunakan metodologi RAD (Rapid Aplication Development). [3]

Rapid Application Development (RAD) atau pengembangan aplikasi cepat, dikemukakan oleh Kendall adalah pendekatan berorientasi objek untuk pengembangan sistem yang meliputi metode pengembangan serta perangkat lunak.

Kendal dan Kendall melihat RAD sebagai metodologi pengembangan sistem yang berusaha untuk mengatasi perubahan persyaratan kebutuhan user dan merekomendasikan RAD untuk mengembangkan aplikasi berbasis web. [4]

Menurut Pressman, RAD merupakan model proses perangkat lunak yang menekankan pada daur pengembangan hidup yang singkat. [5]

Tahapan-tahapan yang harus dilakukan dalam metode RAD ini adalah sebagai berikut :

1. Analisa Persyaratan

Analisis persyaratan bertujuan untuk mengidentifikasikan layanan, batasan, dan objektivitas dari sistem pengumpulan data yang dilakukan. Selain itu, tahap analisis persyaratan juga bertujuan untuk mendefinisikan persyaratan pengguna dan sistem.

Pada tahap ini terdiri atas 3 aktivitas yang akan dikerjakan yaitu sebagai berikut :

a. Komunikasi dan Perencanaan Tujuan dari komunikasi dan perencanaan proyek adalah untuk menghasilkan manajemen perubahan persyaratan dan manajemen resiko. 
b. Spesifikasi Sistem

Tujuan dari spesifikasi sistem adalah menjelaskan kebutuhan dan keinginan akan adanya sistem informasi.

c. Spesifikasi Pengguna

Tujuan dari spesifikasi pengguna adalah untuk mengidentifikasi kebutuhan user mengenai apa yang akan dicapai oleh proyek ini.

2. Analisa Modeling

Tahap ini memiliki tujuan untuk menganalisis semua kegiatan dalam arsitektur sistem secara keseluruhan dengan melibatkan identifikasi dan deskripsi abstraksi sistem perangkat lunak yang mendasar dan hubungan-hubungannya. Aktivitas yang akan dilakukan adalah sebagai berikut :

a. Use-case Diagram

Use-case diagram dirancang untuk menunjukkan secara umum fungsi dan tanggung jawab masing-masing aktor dalam sistem informasi produk unggulan daerah usaha kecil menengah.

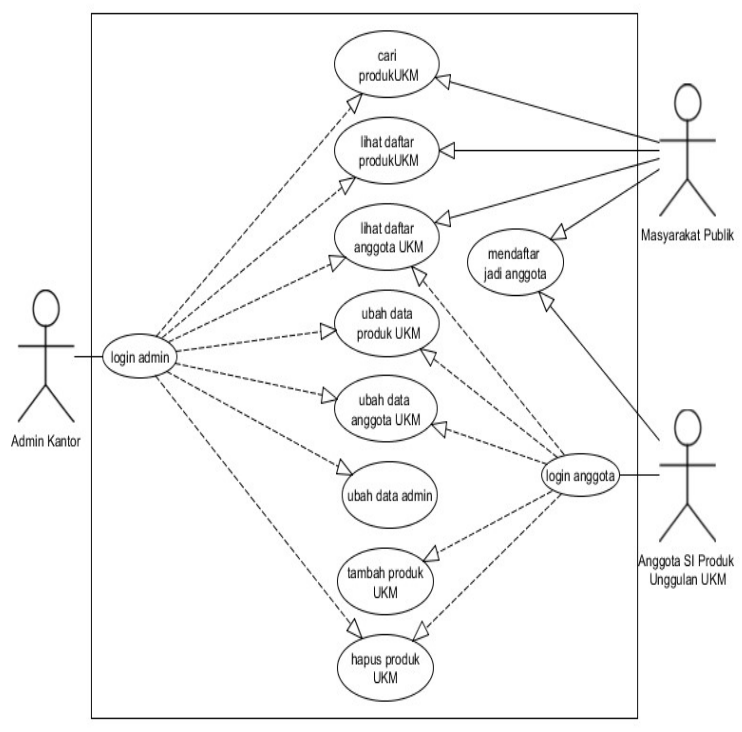

Gambar 2. Use-case Diagram daftar produk, data UKM, fitur masuk dan fitur registrasi untuk anggota UKM.

2. Tampilan 2 menjelaskan fitur registrasi untuk anggota UKM yang ingin mendaftar.

3. Tampilan 3 menjelaskan tentang fitur masuk dengan memasukkan username dan password dari akun anggota UKM.

4. Tampilan 4 menjelaskan tentang informasi kontak.

5. Tampilan 5 menjelaskan tentang fitur search produk berdasarkan kategori.

6. Tampilan 6 menjelaskan tentang informasi detail dari produk yang ditampilkan.

7. Tampilan 7 menjelaskan tentang jumlah UKM berdasarkan kabupaten/kota.

8. Tampilan 8 menjelaskan tentang jumlah tenaga kerja UKM berdasarkan kabupaten/kota.

9. Tampilan 9 menjelaskan tentang data tabel daftar UKM yang telah dimasukkan anggota UKM sebelumnya.

10. Tampilan 10 menjelaskan tentang fitur masuk admin kantor.

11. Tampilan 11 menjelaskan tentang halaman home admin kantor yang terdapat data yang telah dimasukkan oleh anggota UKM.

12. Tampilan 12 menjelaskan tentang pengaturan akun admin jika ingin melakukan perubahan admin kantor.

13. Tampilan 13 menjelaskan tentang fitur login anggota UKM yang harus memasukkan username dan password yang sudah registrasi sebelumnya.

14. Tampilan 14 menjelaskan tentang tambah data produk atau memasukkan data produk yang baru.

15. Tampilan 15 menjelaskan tentang hapus data produk jika ada data produk yang ingin dihapus.

16. Tampilan 16 menjelaskan tentang pengaturan akun anggota UKM jika ada anggota yang ingin mengubah data akun anggota.

\section{HASIL DAN PEMBAHASAN}

A. Implementasi Antar Muka

Implementasi antar muka adalah menerjemahkan layout yang sudah dibuat pada desain perancangan antar muka ke dalam bentuk tampilan implementasi sistem secara utuh.

Berikut akan dijelaskan tampilan hasil dari implementasi antar muka, yaitu sebagai berikut:

1. Tampilan 1 menjelaskan tentang halaman depan yang terdapat menu beranda, menu 
1. Tampilan Halaman Depan

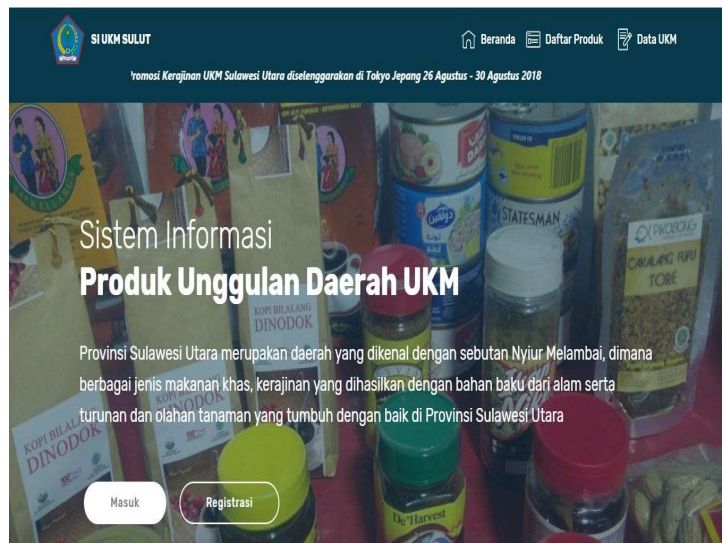

2. Tampilan Fitur Registrasi

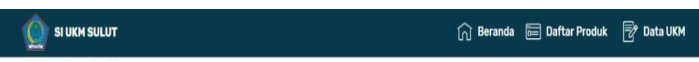

Register

Daftarkan UKM Anda dibawah ini

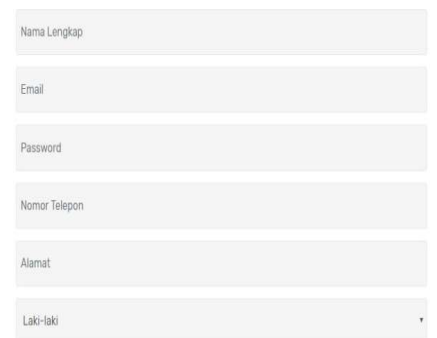

3. Tampilan Fitur Masuk

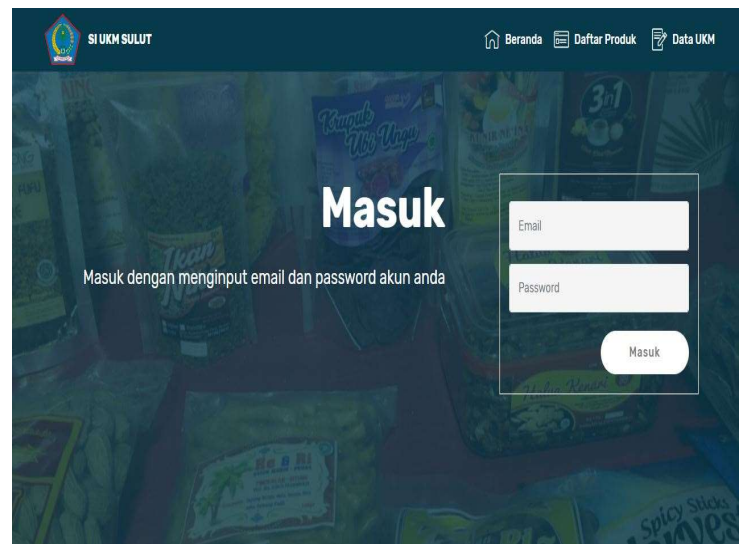

4. Tampilan Informasi Kontak

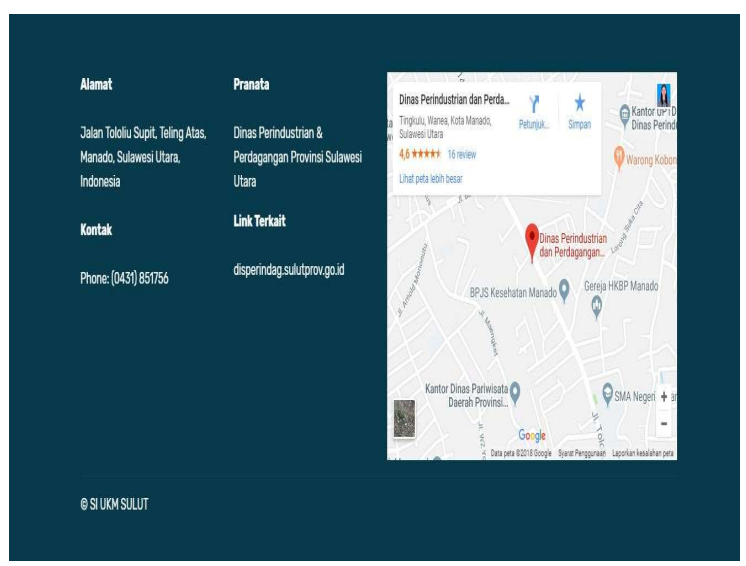

5. Tampilan Fitur Search

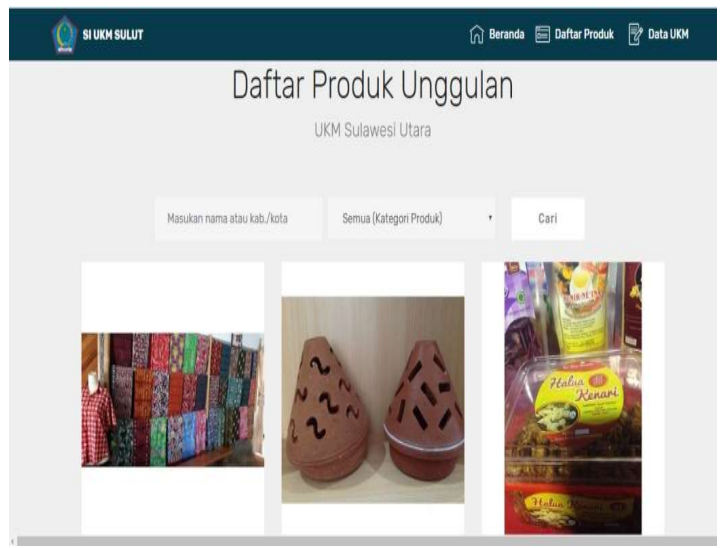

6. Tampilan Informasi Produk

\section{C) suxusuwr}

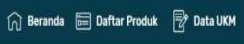

Halua Kenari

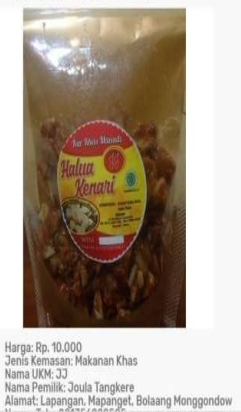

7. Tampilan Jumlah UKM

\begin{tabular}{|c|c|}
\hline Q sumusulur 2018 & 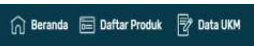 \\
\hline
\end{tabular}

1. Jumlah UMKM

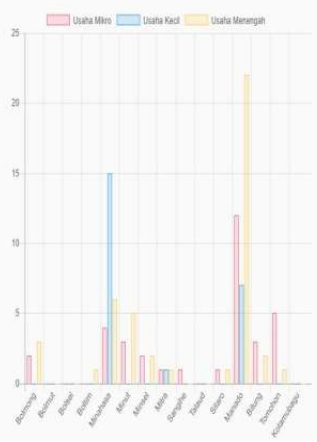

8. Tampilan Jumlah Tenaga Kerja

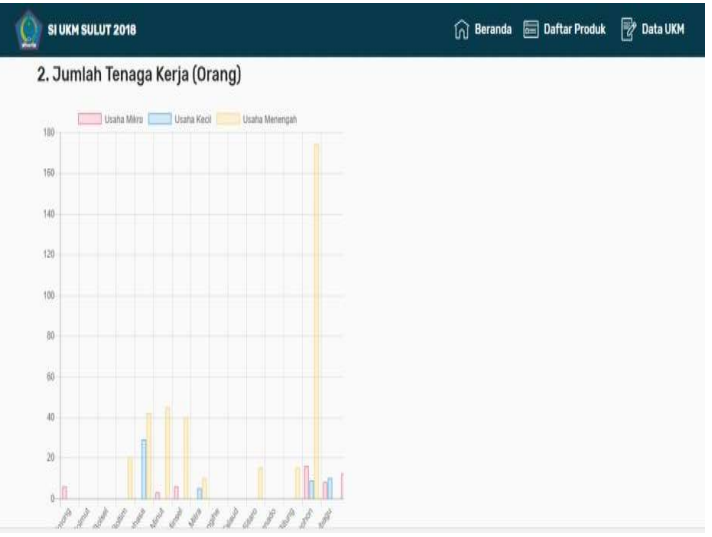


9. Tampilan Tabel Data Daftar UKM

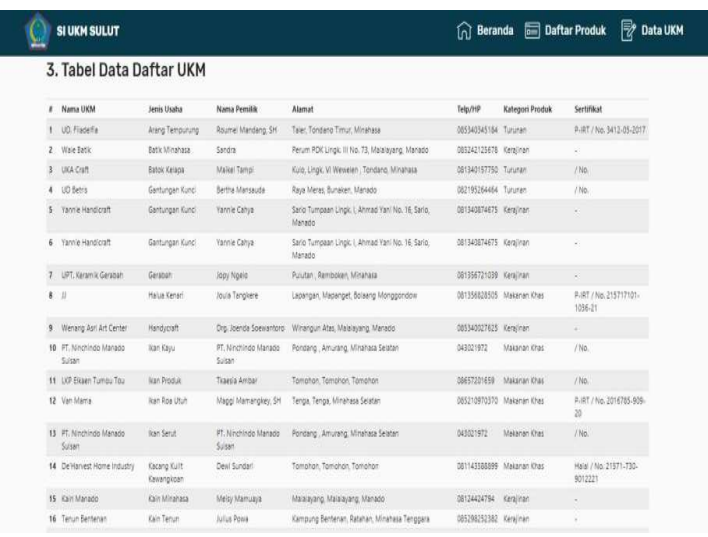

10. Tampilan Masuk Admin

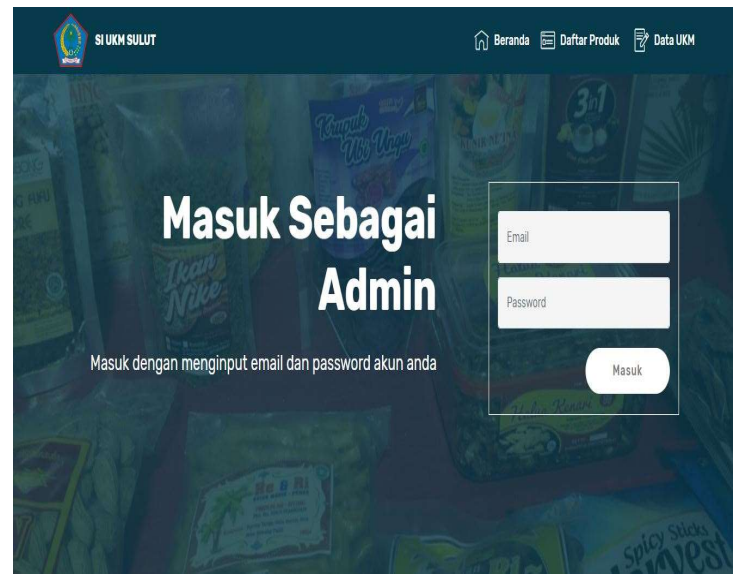

11. Tampilan Home Admin

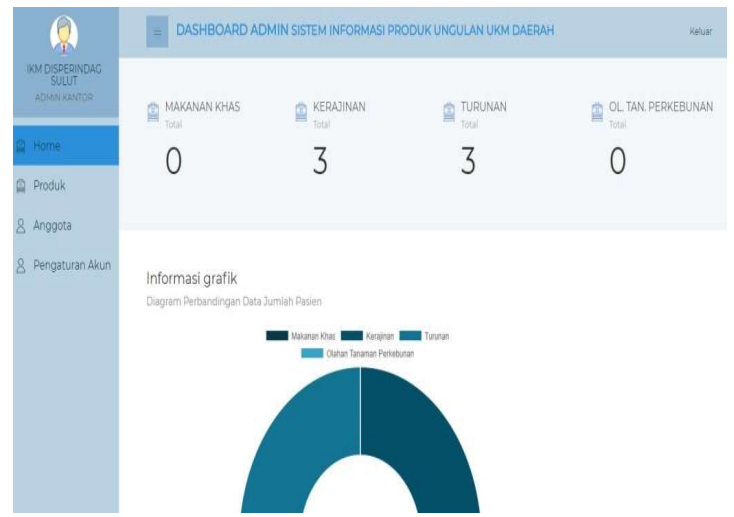

12. Tampilan Pengaturan Akun Admin

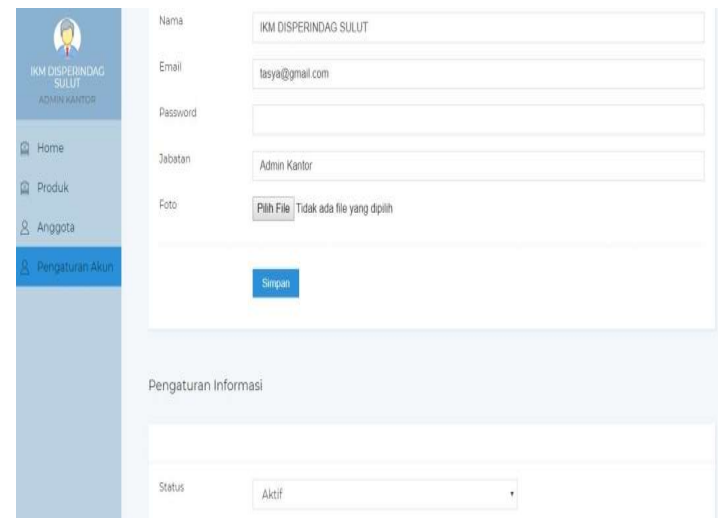

13. Tampilan Login Anggota

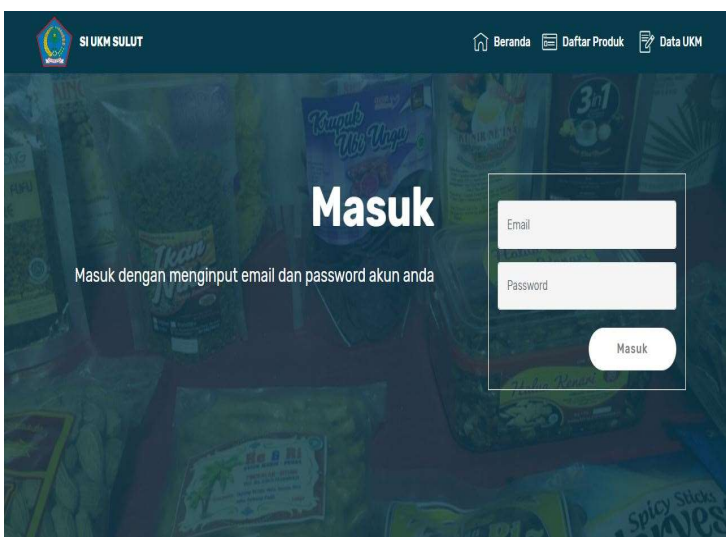

14. Tampilan Tambah Data Produk

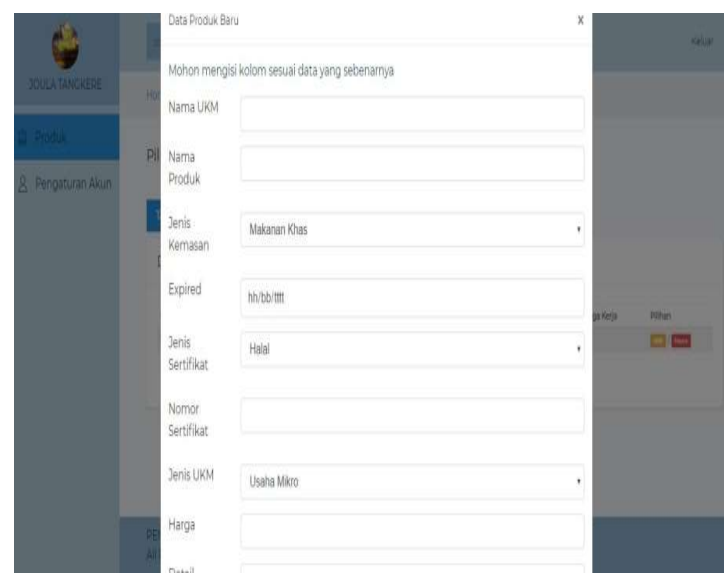

15. Tampilan Hapus Data Produk

Datar Datia ProdukAnda

\begin{tabular}{|c|c|c|c|c|c|}
\hline \# Ban UVAM & Jenis latar & Alannt & Jensisuan & 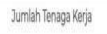 & Pilithn \\
\hline 1 Veme tendionat: & Kang & 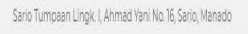 & Winal lenengah & n & 回臮 \\
\hline 2 sant Hancest: & Contugan have & 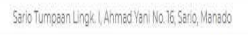 & Uablaneger & 15 & 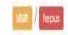 \\
\hline 3 yme tancrat & Canturgantionct & 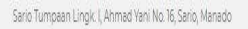 & Usanalenergen & 15 & 网国 \\
\hline 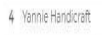 & laving & 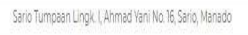 & Usial Wenergat & n & 미뭄 \\
\hline 5 sume inosest & Swakit & 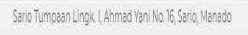 & Unableneng & n & 回回 \\
\hline 6 immethancerst: & koung & 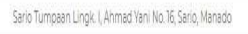 & Wsiral Whengent & 20 & 回国 \\
\hline 7 Yame thancratit & Koung & 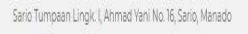 & Usian lenereysed & an & 回国 \\
\hline 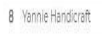 & Contugenture & 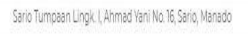 & Usar Whengaht & 15 & 미몽 \\
\hline
\end{tabular}
Botationite

16. Tampilan Pengaturan Akun Anggota

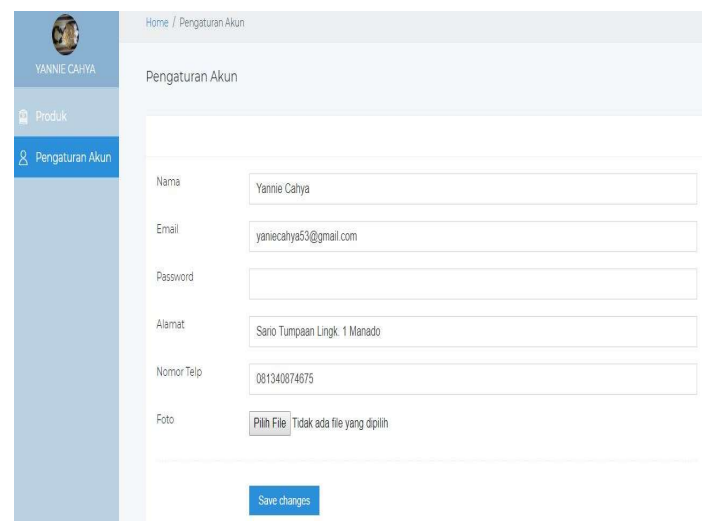




\section{PENUTUP}

\section{A. Kesimpulan}

Penelitian dengan judul "Rancang bangun sistem informasi produk unggulan daerah usaha kecil menengah" menggunakan metode rapid application development (RAD).

Sistem ini memungkinkan pengguna untuk mengetahui dan mengenal produk unggulan daerah usaha kecil menengah berdasarkan kategori jenis produk dan berdasarkan kabupaten/kota. Sistem ini akan lebih memudahkan para anggota UKM untuk mempromosikan hasil produk unggulannya.

\section{B. Saran}

1) Pemerintah dapat memperhatikan dan mengambil peran lebih dalam meningkatkan kualitas produk unggulan daerah.

2) Anggota UKM diharapkan lebih lagi mempromosikan produk unggulan dengan lebih baik.

3) Masyarakat Sulawesi Utara diharapkan dapat melestarikan berbagai produk unggulan daerah agar bisa menjadi nilai jual lebih di pasar internasional dan dapat bersaing dengan produk-produk lokal lainnya.

4) Apabila untuk kedepannya ada yang ingin mengembangkan penelitian ini lebih lanjut, disarankan untuk menambahkan fitur pemesanan produk dan pencarian lokasi berdasarkan tempat usaha.Untuk ukuran dari aplikasi diushakan dibuat lebih kecil lagi agar tidak membutuhkan waktu yang lama dalam menjalankan aplikasi tersebut.

\section{DAFTAR REFERENSI}

[1] Rahmasari Lisda. 2015. Sistem Informasi Berbasis Web Produk Unggulan Usaha Mikro Kecil Menengah (UMKM) di Kota Semarang. Semarang : Fakultas Ekonomi Program Studi Manajemen Universitas AKI.

[2] Nasrudin Multazam. 2016. Analisis Peran Usaha Kecil Menengah (UKM) Terhadap Peningkatan Ekonomi Keluarga Karyawan. Makasar : Fakultas Ekonomi dan Bisnis Islam Univeristas Islam Negeri.

[3] Dalalu Sintia. 2017. Sistem Informasi Terpadu Fakultas Teknik Universitas Sam Ratulangi. Manado : Fakultas Teknik Program Studi Informatika Universitas Sam Ratulangi.

[4] Kendall, K. E. dan Kendall, J. E. 2010. Analisis \& Perancangan Sistem. Jakarta : PT. Indeks.

[5] Pressman. 2002. Rekayasa Perangkat Lunak Pendekatan Praktisi (Buku Satu) : Yogyakarta.
Mambu Oletta. 2016. Pengembangan Aplikasi E-Report Layanan Masyarakat untuk Manado. Manado : Fakultas Teknik Program Studi Informatika Universitas Sam Ratulangi.

[7] Makalalag Dadang. 2016. Sistem Informasi Geografis Monitoring dan Evaluasi Proyek Dinas Pekerjaan Umum Kota Kotamobagu. Manado : Fakultas Teknik Program Studi Informatika Universitas Sam Ratulangi.

[8] Raselawati Ade. 2011. Pengaruh Perkembangan Usaha Kecil Menengah Terhadap Pertumbuhan Ekonomi Pada Sektor UKM di Indonesia. Jakarta : Fakultas Ekonomi dan Bisnis Universitas Islam Negeri Syarif Hidayatullah.

[9] Hans Gary. 2016. Pembuatan Marketplace Penjualan Makanan Khas. Surabaya : Program Studi Teknik Informatika Fakultas Teknologi Industri Universitas Kristen Petra.

\section{SEKILAS TENTANG PENULIS}

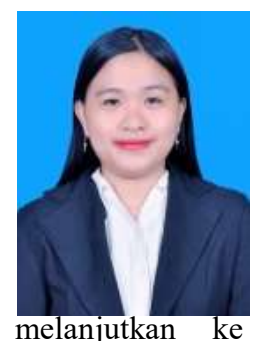

Saya bernama Kauntu Natasya Novia Febriana. Lahir pada tanggal 6 November 1994 di Manado. Anak pertama dari 2 bersaudara. Mulai menempuh pendidikan pada tahun $2000 \mathrm{di}$ SD Katolik 17 St. Tarsisius Karombasan. Kemudian SMP Katolik Hati Kudus Karombasan pada tahun 2006. Setelah itu melanjutkan pendidikan di SMA Negeri 1 Manado pada tahun 2009. Setelah lulus, di tahun 2012 kemudian melanjutkan pendidikan di Universitas Sam Ratulangi Manado, mengambil Program Studi Teknik Informatika di Jurusan Elektro Fakultas Teknik. Penulis membuat skripsi demi memenuhi syarat sarjana (S1) dengan penelitian berjudul Rancang Bangun Sistem Informasi Produk Unggulan Daerah Usaha Kecil Menengah yang dibimbing oleh Yaulie D.Y. Rindengan, ST., MSc., MM dan Alwin M. Sambul, ST., M.Eng., Ph.D, sehingga pada tanggal 23 Agustus 2018 resmi lulus di Teknik Elektro Program Studi Teknik Informatika Universitas Sam Ratulangi Manado dengan menyandang gelar Sarjana Komputer (S.Kom) dan mendapatkan hasil predikat sangat memuaskan. 
